\title{
“The Innate Tail": An Unusual Cause of Rectal Bleeding in an Adult Male
}

\author{
Sujit Padmanabhan Nair ${ }^{a}$ Sanjay Chandnani ${ }^{a}$ Prasanta Debnath ${ }^{a}$ \\ Pravin M. Rathi ${ }^{a}$ Parmeshwar Junare ${ }^{a}$ Vinay Zanwar ${ }^{a}$ Sangeeta Kini ${ }^{b}$ \\ a Department of Gastroenterology, Topiwala National Medical College and B.Y.L. Nair Charitable Hospital, \\ Mumbai, India; ${ }^{b}$ Department of Pathology, Topiwala National Medical College and B.Y.L. Nair Charitable Hospital, \\ Mumbai, India
}

\section{Keywords}

Retrorectal hamartoma · Tailgut cyst · Rectal duplication cyst

\section{Abstract}

Retrorectal cystic hamartomas or tailgut cysts are infrequent congenital lesions presenting as presacral masses originating from the embryonic hindgut. They are commonly diagnosed in middle-aged women. Physicians must have a high index of suspicion to diagnose this rare tumor. We report a case of retrorectal hamartoma in a 70-year-old male presenting as rectal bleeding instead of the usual compressive symptoms. The utility of imaging modalities and the paramount importance of histopathology has been described. The treatment modality is surgical excision to prevent the potential malignant transformation.

(c) 2020 Sociedade Portuguesa de Gastrenterologia Published by S. Karger AG, Basel

\section{A "cauda inata": uma causa incomum de retorragia num homem}

Palavras Chave

Hamartoma retrorretal . Cisto intestinal . Cisto de

duplicação retal

\section{Resumo}

Hamartomas císticos retrorretais ou "tailgut cysts" são lesões congénitas pouco frequentes que se originam do intestino posterior embrionário e que se apresentam como massas pré-sagradas. São comumente diagnosticados em mulheres de meia-idade. Os médicos devem ter um elevado grau de suspeição para diagnosticar este tumor raro. Relatamos um caso de um hamartoma retrorretal num homem com 70 anos de idade que se apresentou com retorragias e não com os sintomas mais comuns de obstrução. A utilidade dos exames de imagem e a grande importância da histopatologia foi demonstrada neste caso. A modalidade terapêutica adoptada foi a excisão cirúrgica para prevenir uma transformação maligna potencial.

๑ 2020 Sociedade Portuguesa de Gastrenterologia Publicado por S. Karger AG, Basel

\section{Introduction}

Retrorectal cystic hamartoma, also called tailgut cyst (TGC) is an uncommon congenital developmental cystic lesion of the presacral area [1]. It arises from postnatal primitive tail gut remnants, which normally involute by the 8 th week of development [2]. It is usually incidentally

karger@karger.com www.karger.com/pjg

Karger BOPEN ACCESS
C) 2020 Sociedade Portuguesa de Gastrenterologia Published by S. Karger AG, Basel

This article is licensed under the Creative Commons AttributionNonCommercial-NoDerivatives 4.0 International License (CC BYNC-ND) (http://www.karger.com/Services/OpenAccessLicense). Usage and distribution for commercial purposes as well as any distribution of modified material requires written permission.
Mumbai 400008 (India)

sujitnair12345@gmail.com 
detected in middle-aged women, with a female-to-male ratio of 3:1 [3]. TGCs are asymptomatic in half of the patients; when symptomatic, they have the compressive effect of a growing mass in the pelvis. Due to the nonspecific nature of the symptoms and the complex anatomical location, a diagnosis is often challenging.

We report an uncommon case of rectal bleeding in an elderly male patient diagnosed as TGC, highlighting the importance of imaging in assessing the characteristics and extension before surgery.

\section{Case Report}

A 70-year-old male presented with hematochezia and perianal pain during defecation for 4 months. There was no history of abdominal pain, constipation, weight loss, or mass prolapsing through the rectum. Pallor was observed on general examination. Rectal examination revealed a palpable mass just above the dentate line. The hemoglobin level was $9 \mathrm{~g} / \mathrm{dL}$, and a peripheral smear demonstrated microcytic hypochromic anemia. Colonoscopy demonstrated a mucosal bulge in the posterior rectal wall (Fig. 1).

Abdominal and pelvic computed tomography (CT) showed a well-defined hypodense lesion $7.2 \times 6.8 \mathrm{~cm}$ in size in the perianal space compressing the rectal and anal canal anteriorly. Pelvic magnetic resonance imaging (MRI) showed a $6.3 \times 6.5 \times 8.5 \mathrm{~cm}$ welldefined unilocular mass in the retrorectal compartment appearing hyperintense on T2W and hypointense on T1W images with mild peripheral enhancement (Fig. 2a, b). Anteriorly, it compressed the rectum without visible communication, and no invasion of adjacent structures was documented.
Radial endoscopic ultrasound (EUS) demonstrated a well-defined cystic lesion with some hyperechoic content surrounded by a distinct hypoechoic layer measuring $7.6 \times 4.7 \mathrm{~cm}$ arising in the perirectal area above the anal verge (Fig. 3). No involvement of the rectal wall and sphincter complex was documented. Adenopathies were not identified.

The patient was operated through a perianal approach, and complete excision of the cyst was achieved. Gross examination revealed an irregularly shaped ovoid multiloculated cyst measuring $7 \times 5 \mathrm{~cm}$ in the greatest diameter (Fig. 4). On histopathology, the cyst wall lining consisted of a stratified squamous epithelium and mixed inflammation with foreign body giant cell reaction with thick fibrocollagenous tissue underneath (Fig. 5a, b). There was no evidence of malignancy or ectopic tissue. This confirmed the diagnosis of a TGC. The patient was discharged and is being followed in the outpatient department without recurrence.

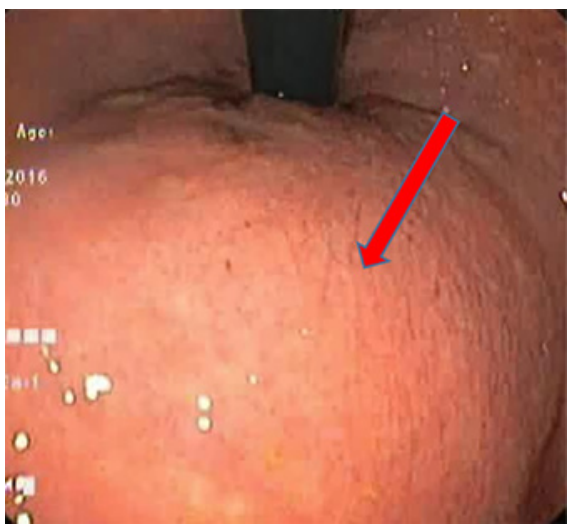

Fig. 1. Colonoscopy demonstrating a mucosal bulge in the posterior wall of the rectum (red solid arrow).
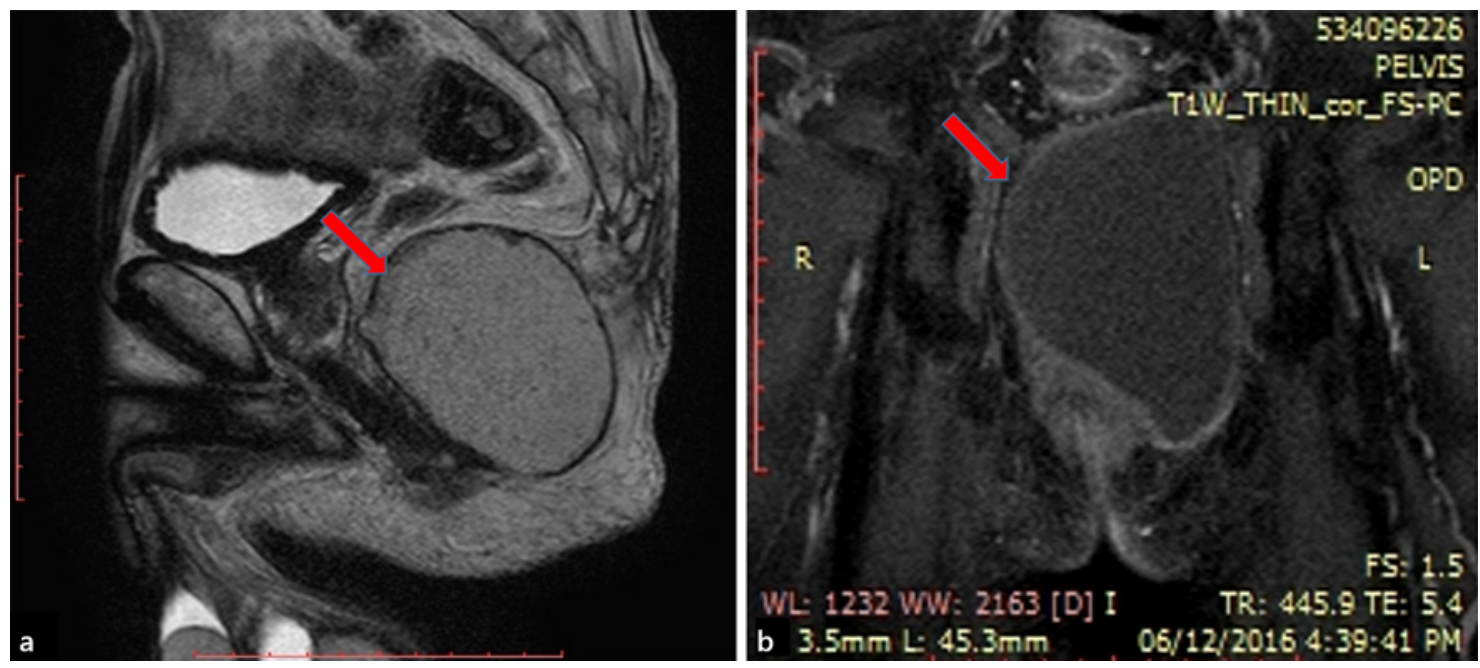

Fig. 2. a Pelvic MRI demonstrating a retrorectal mass displacing the rectum anteriorly and extending inferiorly beyond the coccyx. The mass shows hyperintensity on T2W imaging with mild peripheral enhancement (solid red arrow). b The retrorectal mass demonstrates hypointensity on T1W imaging (solid red arrow). 


\section{Discussion}

The retrorectal space is a loose areolar tissue plane consisting of totipotent cells, confined by the posterior rectal wall anteriorly and the sacrum posteriorly. The ureter, sacral nerve roots, and iliac vessels form the lateral border of this space [4]. Retrorectal lesions are rare clinical entities, with reports estimating an incidence of 1 : 40,000 to 63,000 [5]. These cysts are classified as teratomas or dermoid, neurenteric, epidermoid, or enteric cysts (TGCs and rectal duplication cysts) depending on the embryonic cells of origin [6]. They are more common among middle-aged women, which is possibly related to a more significant number of cases incidentally detected during gynecological examinations. Among men, malig- nant lesions are more common, due to delays in diagnosis [7]. In our case, a TGC presented in the rare form of rectal bleeding in a male of advanced age.

Hjermstad and Helwig [8] reported 53 cases of TGC, of which $51 \%$ presented with perianal pain and none presented with rectal bleeding. Other presenting features are compressive symptoms like chronic constipation, urinary retention, recurrent perianal infections causing retrorectal abscesses, or a history of multiple surgeries for anal fistulae [9]. The use of CT, MRI, and EUS has improved physicians' ability to diagnose these rare tumors. Cystic, solid, or mixed lesions can be distinguished on pelvic CT or MRI delineating soft tissue planes and demonstrating the relationship of the lesions with the sacrum, muscles, and nerves. MRI has been shown to be superior

Fig. 3. Radial EUS demonstrating a welldefined cystic lesion $7.6 \times 4.7 \mathrm{~cm}$ in size in the perirectal area, above the anal verge, with a distinct hypoechoic layer around it. Fig. 4. The cyst was completely excised by a posterior approach. Grossly, the cyst measured $7 \times 5 \mathrm{~cm}$ and was ovoid and multiloculated.
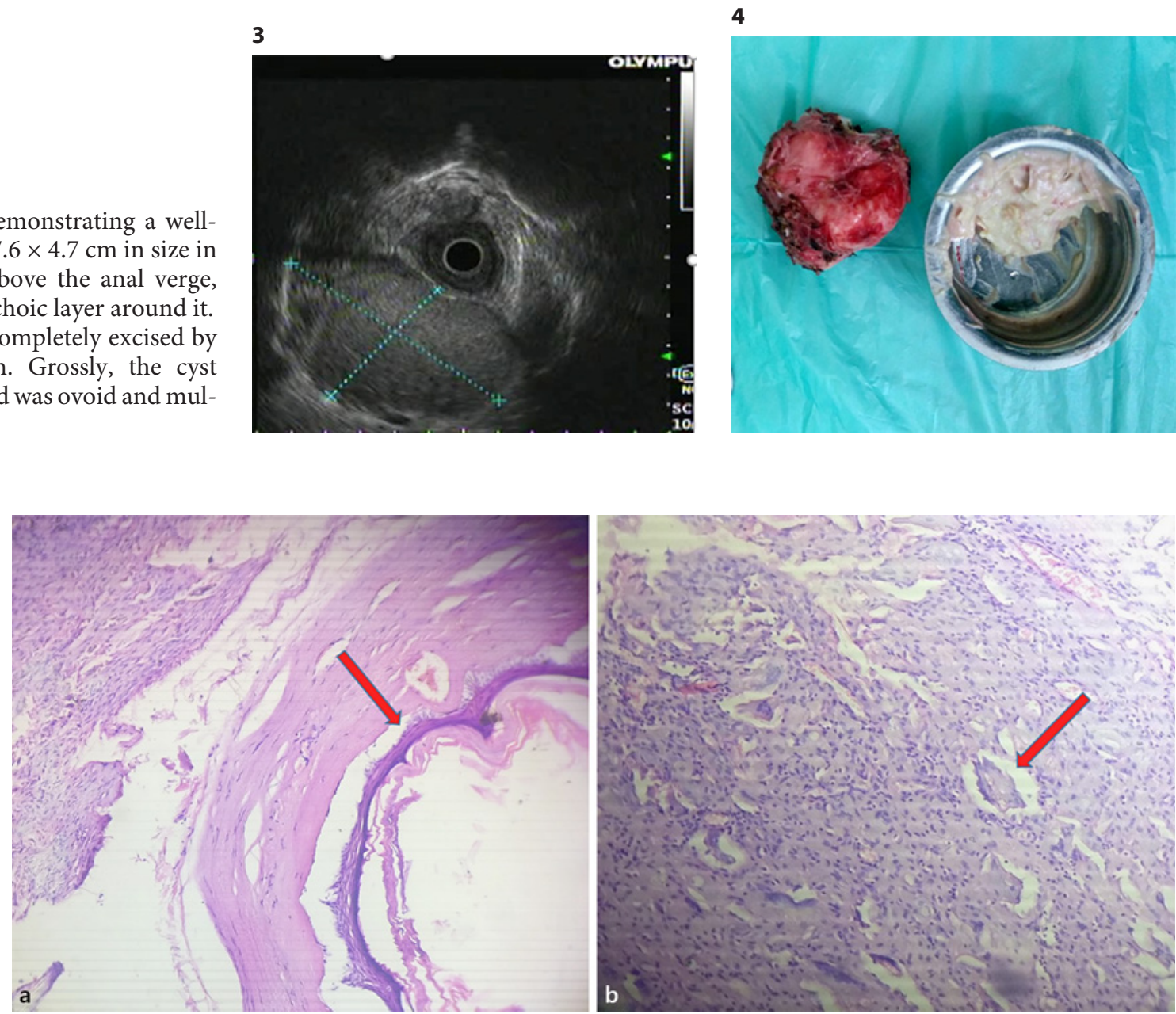

Fig. 5. a Cyst wall showing a stratified squamous epithelial lining with thick fibrocollagenous tissue underneath (red solid arrow). The subepithelium shows dense mixed inflammation. Hematoxylin-eosin. Original magnification, $\times 20$. b Cyst wall lining showing mixed inflammation with numerous foreign body giant cells (red solid arrow). Hematoxylin-eosin. Original magnification, $\times 80$. 
to $\mathrm{CT}$ in providing a correct diagnosis of the type of retrorectal tumor, but the radiological diagnosis correlated with histopathology in only $16 \%$ to $28 \%$ of the cases for CT and MRI, respectively [10].

EUS fine-needle aspiration (FNA) of the cystic lesion is not advised, due to the low diagnostic yield and risks of cyst infection and of spilling malignant cells. However, there have been a few case reports indicating the utility of EUS FNA in the diagnosis of such lesions [11, 12]. The role of EUS FNA in these tumors requires further validation, and biopsy can be attempted only when the risk of malignancy by other imaging modalities has been excluded. Considering the above facts, EUS-guided FNA was not performed on our patient. In the present case, the imaging modalities narrowed down our hypothesis to a rectal duplication cyst and TGC. Its differentiation based only on these examinations is very challenging.

Our patient underwent a complete cyst excision by the posterior approach, and the intraoperative findings indicated no invasion of the rectal wall. Complete surgical resection and histopathology remain the mainstay of both diagnosis and definitive treatment. An anterior (transabdominal) approach is reserved for lesions above the sacral promontory and a posterior approach for lesions below the sacral promontory [13]. A combined approach may be used for large tumors extending on either side of the promontory [14]. Sakr et al. [15], in their single-center experience of 24 TGCs, performed excisions by an anterior (transabdominal), posterior (paracoccygeal), and combined (anterior plus posterior) approach for supralevator, infralevator, and multilocular cysts larger than $10 \mathrm{~cm}$, respectively. To prevent recurrence and potential malignant transformation, complete excision is advised. Malignant transformation of the cyst into an adenocarcinoma, especially in males, confers a poor prognosis [13]. Nicoll et al. [16], in a recent systematic review, reported malignant transformation in $26 \%$ of their TGCs, with a male predominance. Sakr et al. [15] reported malignancy in $8 \%$ of their 24 cases of TGC.

The cyst was multiloculated on gross examination, and histopathology demonstrated that the cyst wall was lined by a stratified squamous epithelium with areas of inflammation and giant cell reaction and fibrocollagenous tissue. Hjermstad and Helwig [8] reported the majority of lesions as multiloculated and multicystic with a wide range of epithelial types lining the cyst wall. The most commonly encountered was squamous metaplasia, secondary to inflammation. A well-developed smooth muscle layer with a nerve plexus and a cyst lining by villi, crypts, and glands differentiate rectal duplication cysts

from TGCs [17]. Teratomas and dermoid cysts differ from TGCs by the presence of components from the three germ layers.

A diagnosis of TGC was established in our patient considering the presacral location and multilocular nature of the cyst lined by squamous epithelial cells on histology. This report adds to the sparse literature on TGCs, in this case presenting in an advanced aged male with rectal bleeding. Different imaging modalities may show specific signs, but the core of diagnosis and treatment remains histopathology and surgical excision, respectively.

\section{Statement of Ethics}

Informed consent for publication of case details was obtained from the patient and relatives.

\section{Conflict of Interest Statement}

None to disclose.

Funding Sources

No funding was received.

\section{Author Contributions}

Conceptualization: S.P. Nair. Data curation: S.P. Nair, P.M. Rathi. Formal analysis: S.P. Nair, P.M. Rathi, S. Chandnani. Investigation: S.P. Nair, S. Kini. Methodology: S.P. Nair, V. Zanwar. Project administration: S.P. Nair. Resources and software: S.P. Nair, P. Junare. Supervision: P.M. Rathi. Visualization: S.P. Nair. Writing original draft: S.P. Nair. Writing review and editing: P.M. Rathi, S.P. Nair, P. Debnath.

References

GE Port J Gastroenterol 2021;28:349-353 DOI: $10.1159 / 000510783$
1 Pyo DJ. Tailgut cyst (retrorectal cyst hamartoma): case report and review. Mt Sinai J Med. 1990 Sep;57(4):249-52.

2 Smit R, Gregorini D, Beltrán R, Martorelli J, Granada G, Lespi P. [Retrorectal cyst hamartoma: report of a pediatric case]. Arch Argent Pediatr. 2010 Jun;108(3):e82-5.

3 Sriganeshan V, Alexis JB. A 37-year-old woman with a presacral mass. Tailgut cyst (retrorectal cystic hamartoma). Arch Pathol Lab Med. 2006 May;130(5):e77-8.

4 Yang BL, Gu YF, Shao WJ, Chen HJ, Sun GD, Jin HY, et al. Retrorectal tumors in adults: magnetic resonance imaging findings. World J Gastroenterol. 2010 Dec;16(46):5822-9. 
5 Jao SW, Beart RW Jr, Spencer RJ, Reiman HM, Ilstrup DM. Retrorectal tumors. Mayo Clinic experience, 1960-1979. Dis Colon Rectum. 1985 Sep;28(9):644-52.

6 Rosa G, Lolli P, Vergine M, El-Dalati G, Malleo G. Surgical excision of developmental retrorectal cysts: results with long-term followup from a single institution. Updates Surg. 2012 Dec;64(4):279-84.

7 Boscà $\mathrm{A}$, Pous S, Artés MJ, Gómez F, Granero Castro P, García-Granero E. Tumours of the retrorectal space: management and outcome of a heterogeneous group of diseases. Colorectal Dis. 2012 Nov;14(11):1418-23.

8 Hjermstad BM, Helwig EB. Tailgut cysts. Report of 53 cases. Am J Clin Pathol. 1988 Feb; 89(2):139-47.
9 Peter P, George U, Peacock M. Retrorectal hamartoma: a 'tail' of two cysts! Indian J Radiol Imaging. 2010 May;20(2):129-31.

10 Glasgow SC, Birnbaum EH, Lowney JK, Fleshman JW, Kodner IJ, Mutch DG, et al. Retrorectal tumors: a diagnostic and therapeutic challenge. Dis Colon Rectum. 2005 Aug;48(8):1581-7.

11 Rathinamanickam H, Pawa S. A tailgut cyst diagnosed by endoscopic ultrasound-guided fine-needle aspiration. ACG Case Rep J. 2015 Oct;3(1):33-5.

12 Hall DA, Pu RT, Pang Y. Diagnosis of foregut and tailgut cysts by endosonographically guided fine-needle aspiration. Diagn Cytopathol. 2007 Jan;35(1):43-6.

13 Miyamoto R, Nagai K, Kemmochi A, Inagawa $S$, Yamamoto M. Surgical Management of Tailgut Cysts: A Report of Two Cases. Int Surg. 2016 Jul;101(7-8):328-33.
14 Umar T, Mikel JJ, Poller DN. Carcinoma arising in a tailgut cyst diagnosed on fine needle aspiration (FNA) cytology. Cytopathology. 2000 Apr;11(2):129-32.

15 Sakr A, Kim HS, Han YD, Cho MS, Hur H, Min BS, et al. Single-Center Experience of 24 Cases of Tailgut Cyst. Ann Coloproctol. 2019 Oct;35(5):268-74.

16 Nicoll K, Bartrop C, Walsh S, Foster R, Duncan G, Payne C, et al. Malignant transformation of tailgut cysts is significantly higher than previously reported: systematic review of cases in the literature. Colorectal Dis. 2019 Aug; 21(8):869-78.

17 Piura B, Rabinovich A, Sinelnikov I, Delgado $B$. Tailgut cyst initially misdiagnosed as ovarian tumor. Arch Gynecol Obstet. 2005 Oct; 272(4):301-3. 